\title{
CFD Analysis of Diverse Serrated Blade Configuration Effects on Fluid Flow of a Modified Centrifugal Fan
}

\author{
Zaimar $^{1, \text { a }}$ \\ ${ }^{1}$ Study Program of Agro-Industry, Agriculture Polythecnics of Pangkep State \\ Pangkep Regency, South Sulawesi 90665, Indonesia \\ azaimarpolitani@gmail.com
}

\begin{abstract}
Abstrak.
Makalah ini menyajikan efek dari konfigurasi blade bergerigi yang beragam pada karakteristik aliran udara dari kipas sentrifugal yang dimodifikasi oleh CFD. Aplikasi ini diteliti untuk meningkatkan kinerja aerodinamis. Konfigurasi ini (USB, ISB, USB, OSB) disimulasikan pada tingkat kecepatan impeler oleh CFD. Kemudian diuji untuk menganalisis nilai karakteristik aliran udara dengan uji ANCOVA.

Hasil simulasi menunjukkan bahwa konfigurasi BSB mencapai tekanan statik tinggi sekitar 84,5214,7 Pa pada zona dinding. Sedangkan ISB menghasilkan TKE yang lebih rendah di semua zona, kecuali di zona impeller. Ini menghasilkan sekitar 0,51-12,47 m2s-2 TKE di zona dinding. Hasil pengujian ANCOVA menunjukkan bahwa pengaruh kecepatan impeler sangat nyata $(\alpha<0,01)$ terhadap karakteristik aliran udara di semua zona, kecuali tekanan statik yang tidak signifikan $(\alpha>$ $0,05)$ di zona impeler dan aliran fluida. Pengaruh konfigurasi sudu bergerigi sangat signifikan terhadap tekanan statik di zona masuk dan dinding, dan signifikan $(\alpha<0,05)$ di zona aliran fluida. Sedangkan pengaruh terhadap kecepatan udara di daerah impeller, aliran fluida, dan zona dinding sangat signifikan, dan sangat signifikan terhadap TKE di zona impeller dan zona outlet.
\end{abstract}

Kata kunci. karakteristik aliran fluida, kipas sentrifugal, analisis CFD, konfigurasi blade bergerigi

\section{Abstract.}

This paper presents the effects of the diverse serrated blade configurations on airflow characteristics of a modified centrifugal fan by CFD. This application is investigated to improve aerodynamic performance. These configurations (USB, ISB, USB, OSB) are simulated at the impeller speed levels by CFD. Then tested to analyze airflow characteristic values by ANCOVA test.

The simulation results show that the BSB configuration achieves the high static pressures about 84.5214.7 $\mathrm{Pa}$ in the wall zone. While the ISB generates the lower TKE in all the zones, except in the impeller zone. It produces about $0.51-12.47 \mathrm{~m}^{2} \mathrm{~s}^{-2} \mathrm{TKE}$ in the wall zone. The ANCOVA test results indicate that the effects of the impeller speed are very significant $(\alpha<0.01)$ on the airflow characteristics in all the zones, except for static pressure is no significant $(\alpha>0.05)$ in the impeller and fluid flow zone. The effect of the serrated blade configurations is very significant on static pressure in the inlet and wall zone, and significant $(\alpha<0.05)$ in the fluid flow zone. While it is very significant to air velocity in the impeller, fluid flow, and wall zone, and very significant on TKE in the impeller zone and outlet zone.

Keywords: fluid flow characteristics, centrifugal fan, CFD analysis, serrated blade configurations

\section{Nomenclatures}

$\begin{array}{ll}\text { BSB } & : \text { both sides of serrated blades } \\ \text { ISB } & : \text { inside of serrated blades }\end{array}$




$\begin{array}{ll}\text { OSB } & : \text { outside of serrated blades } \\ \text { USB } & : \text { un-serrated blades } \\ \text { TKE } & : \text { turbulent kinetic energy } \\ \text { ANCOVA } & : \text { analysis of covariance } \\ \text { CFD } & : \text { computational of fluid dynamics } \\ \alpha & : \text { level of confidence }\end{array}$

\section{INTRODUCTION}

Centrifugal fan was widely used in industry, especially for flowing air, particular, and sediment. This condition could come through resistance and disturbance flow. The solution problem to overcome it is an improvement of aerodynamic performance. This focused to ensure the design part running well [1]. Fan blades is an important part because can produce the conversion of energy and aerodynamics [2]. Besides that, it also produces pressure for overcoming flow resistance [3].

The structure change of blades could affect fluid flow in a centrifugal fan, namely component part, shape, and dimension [4,5]. By changing of the impeller blade geometry caused fluid flow became unsteady. There were three types of blades namely irregular blade spacing, different blades number, smaller inlet diameter of the impeller. The all three were evaluated by a reference impeller towards the fan performance [6]. In the axial fan, the pressure gradient distributions were affected by the change of the blade structure $[7,8]$. The optimization of structure on the tail edge of trailing edge structures caused the pressure differences and pressure fluctuations become smaller [9]. And it also could reduce the larger turbulent of airfoil [10]. A design of the blades likely as the serrations of trailing edge serration was explored that related to flow and pressure characteristics of the axial fan blades [9]. The serrated airfoil in the form of sharp sawtooth had been researched through detailing literature review of the aerodynamic performance [11]. In the axial fan, applying the serrated blades could decrease static and total pressure of airflow. This due to reduce the turning currents. In this case the absolute tangential velocity in the valley in the serration found about $18 \%$ decreased and the axial velocity found about $19 \%$ increased [12]. Meanwhile, the cases about positioning on the trailing edge of serration and influence on the aerodynamic characteristics of the wing was observed [13].

One modification of the blade impeller is equipping a centrifugal fan with the serrated blades. As consequence, this might affect their fluid flow characteristics [14]. The CFD software as the essence technology in fans, pumps, and fluid devices had long been used successfully, especially in the analysis of fluid flow [15]. Advantages of using CFD are a working design becomes simpler and shorter. Making geometric models using it is easier to do without spending a lot of cost to get the optimal model in a design research. Meanwhile, the experimental method needs longer time and working complicated $[16,17,18]$. A design analysis by using it could analyze a complex flow and improve of the flow pattern in the centrifugal fan system [19].

\section{MATERIALS AND METHOD}

\section{Simulation Design}

The CFD simulation for determining airflow characteristics in the centrifugal fan was begun by making the geometry according to the design results. The design was continued with making of the Grid/Mesh. It used unstructured element model Tetra/Hybrid and T-grid type, size interval of 1 . This was done using software GAMBIT 2.4.6. The results of the design and meshing can be seen in Table 1 and Fig. 1. 
Table 1. Basic geometry of the modified centrifugal fan with serrated blade configurations

\begin{tabular}{|l|c|c|c|c|}
\hline \multirow{2}{*}{\multicolumn{1}{c|}{ Description }} & \multicolumn{4}{c|}{ Dimension } \\
\cline { 2 - 5 } & USB & ISB & OSB & BSB \\
\hline Number of blades & 16 & 16 & 16 & 16 \\
Number of serrated blade sides & 0 & 16 & 16 & 32 \\
Surface area of blades $\left(\mathrm{m}^{2}\right)$ & 0.096 & 0.092 & 0.092 & 0.087 \\
Impeller diameter (m) & 0.35 & 0.35 & 0.35 & 0.35 \\
Inlet diameter (m) & 0.27 & 0.27 & 0.27 & 0.27 \\
Outlet area of rectangular (m) & 0.20 & 0.20 & 0.20 & 0.20 \\
Volute diameter (m) & 0.40 & 0.40 & 0.40 & 0.40 \\
Volute tongue diameter (m) & 0.22 & 0.22 & 0.22 & 0.22 \\
\hline
\end{tabular}

In reference [20] Meshing is a technique to divide an object into smaller parts. Checking the mesh quality is good, then that should be done with far value Equal-Angle Skew not exceeding of 0.9. Researcher [21] one way to get a good geometric model is a design made good, simple, and avoids unnecessary surfaces. The selection of meshing techniques might produce different mesh parameters so that accuracy is needed to get the best meshing.

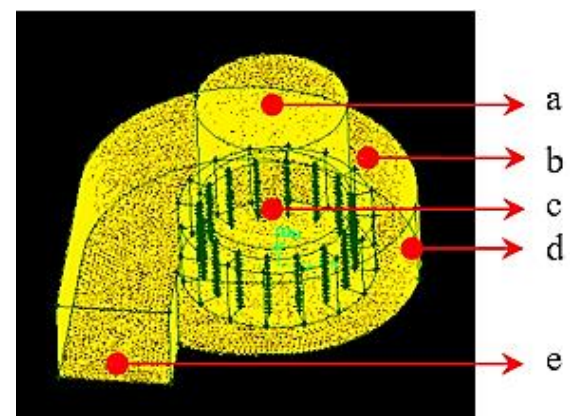

Fig. 1. Mesh-3D model and zones of the modified centrifugal fan.

(a) inlet zone, (b) fluid flow zone, (c) impeller zone, (d) wall zone, and (e) outlet zone

Table 2. The grid size of meshing in the modified centrifugal fan with diverse serrated blade configurations

\begin{tabular}{|c|c|c|c|}
\hline $\begin{array}{c}\text { Serrated blade } \\
\text { configurations }\end{array}$ & Cells & Faces & Nodes \\
\hline USB & 389357 & 799445 & 74938 \\
ISB & 400245 & 821521 & 76945 \\
OSB & 397637 & 816829 & 76792 \\
BSB & 411070 & 844638 & 79391 \\
\hline
\end{tabular}

The important stages of the simulation are geometry completion, meshing, and determining of the boundary condition. The next stage is to determine the boundary condition (Table 2 and 3 ). This is done to limit the portion to be analyzed by the software. The final stage is to export the mesh. If the geometry files in the form of GAMBIT software directly can be exported in the FLUENT program. The next of the process simulation was continued using the ANSYS FLUENT 6.3.26. This underwent the several stages. The final stage is a solution running calculation until convergent is achieved [20]. 
Table 3. Setting of the boundary conditions

\begin{tabular}{|l|l|}
\hline \multicolumn{1}{|c|}{ Boundary conditions } & \multicolumn{1}{c|}{ Values } \\
\hline General settings & $\begin{array}{l}\text { 3D, scale in cm, pressure-based type, velocity } \\
\text { formulation, and time steady }\end{array}$ \\
\hline Alternative model & $\begin{array}{l}\text { Model k-epsilon (2-eqn) standard and viscous } \\
\text { model }\end{array}$ \\
\hline Materials & $\begin{array}{l}\text { Air with density of } 1.125 \mathrm{~kg} \mathrm{~m}^{-3} \text { and kinematic } \\
\text { viscosity of } 1.7894 \mathrm{e}-05 \mathrm{~Pa} \mathrm{~s} \text { (standard) }\end{array}$ \\
\hline Setting of boundary conditions & $\begin{array}{l}\text { Velocity inlet, pressure outlet, impeller, wall, } \\
\text { fluid flow zone, and interior default }\end{array}$ \\
\hline Solution of Navier Stokes eq. & Simple algorithm \\
\hline The impeller speeds & $400 ; 600 ; 800 ;$ and $1000 \mathrm{RPM}^{-1}$ \\
\hline $\begin{array}{l}\text { Initial velocities from } \\
\text { experiment data }\end{array}$ & $2.47 ; 2,82 ; 3.16 ;$ and $3.80 \mathrm{~m} \mathrm{~s}^{-1}$ \\
\hline
\end{tabular}

\section{Simulation Data Analysis}

The simulation analysis gives the input parameters of the serrated blade configurations and impeller speeds. The formation of the serrated blade generally formed sharp sawtooth that applied. While these configurations consist of the USB, ISB, OSB, and BSB, as shown in Fig. 2. The impeller speeds consist of 400,600, 800, and 1000 RPM. Both parameters are as independent variables. Whereas, the output parameters consist of static and dynamic pressure, air velocity, and TKE, as dependent variables. The configuration of serrated blades is qualitative variables so function as a fixed factor. The impeller speed is a quantitative variable as a covariate factor. The test used the factorial design. Thus, it was analyzed by ANCOVA test with the SPSS version 21.

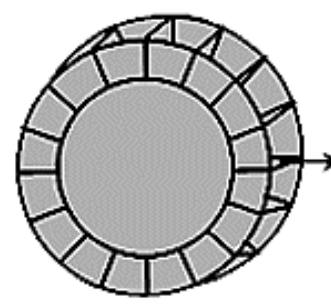

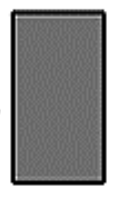

(a)

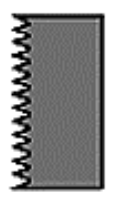

(b)

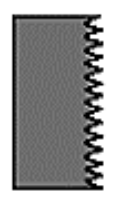

(c)

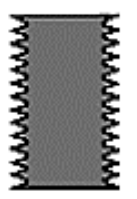

(d)

Fig. 2. The saw tooth serrated blade configurations of radial type impeller.

(a) USB, (b) ISB, (c) OSB, and (d) BSB configurations

\section{RESULTS AND DISCUSSION}

The all data that obtained from CFD simulation are average values of static and dynamic pressure, air velocity, and TKE. These values included in each zone of inlet, outlet, impeller, wall, and fluid flow. The fluid flow zone is lain between the impeller and the casing wall of the modified centrifugal fan.

\section{Static and Dynamic Pressure}

The results of static pressure on the serrated blade configurations and impeller speeds in the inlet zone that illustrated in Fig. 3a. It indicated that the ISB configuration produces the static pressure values different from the other configuration in the inlet zone. An attractive phenomenon showed that all the impeller levels generate the lowest static pressures. Especially in the range of 600-800 RPM achieve static pressures about 17.39-22.77 Pa. 

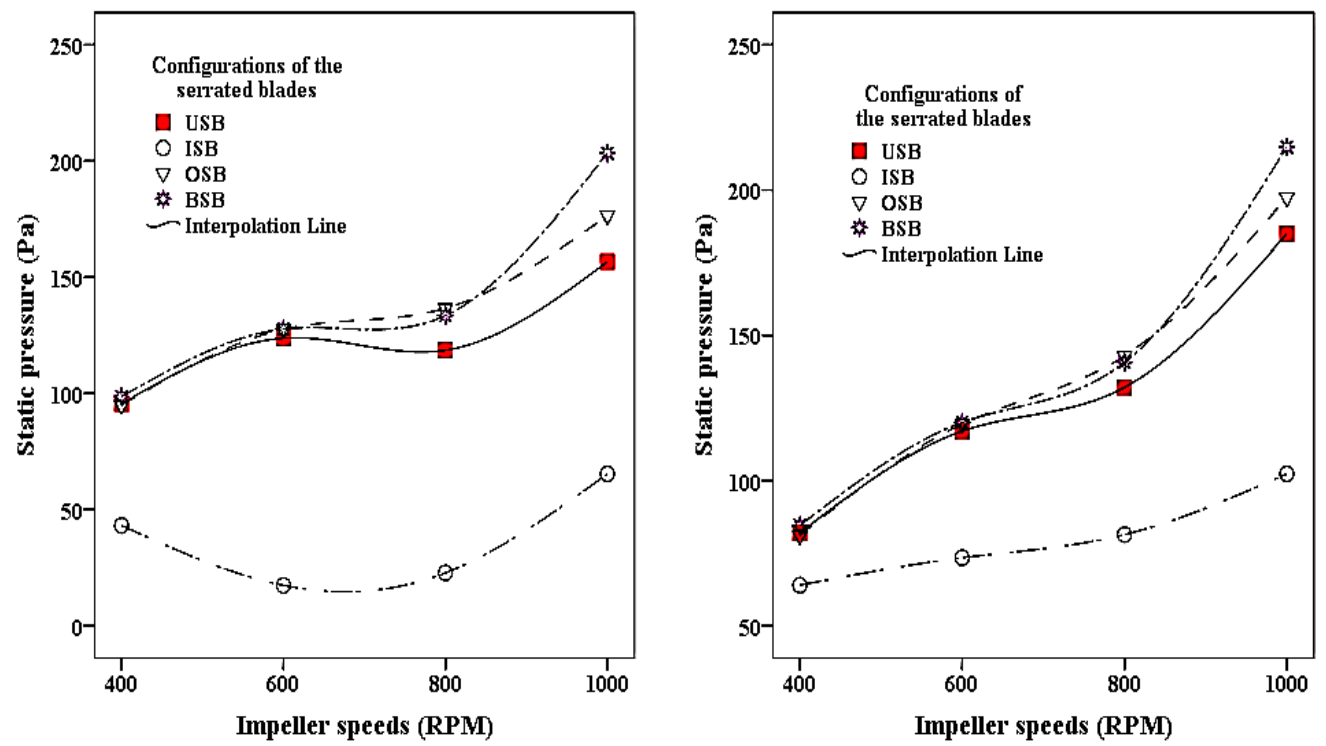

Fig. 3. The result of static pressure in (a) the inlet zone and (b) impeller zone

The results of static pressure in the impeller zone (Fig. 3b) indicated that increasing speed of impeller cause decreasing static pressure at the lower speed, except at 800 to 1000 RPM for all configurations of the serrated blade. The BSB configuration reached the lower values of static pressure in the range of 7.61-10.4 $\mathrm{Pa}$ at the high speed (800 to $1000 \mathrm{RPM}$ ), while the ISB configuration had static pressure in the range of 15.4-43.4 Pa at the lower speeds (below $800 \mathrm{RPM}$ ). These are compared with the others (USB, BSB, OSB), as shown in Fig. 3b. In reference [9] the serrated blades could reduce flow turns so that it could reduce static and total pressure in the axial fan.

The CFD simulation results obtained the lower values of static pressure on the impeller speed of 800 RPM and ISB configuration for all zones. This is illustrated at the graphical simulation in Fig. 4 , where the contour it colored darklish and the line density are loose.

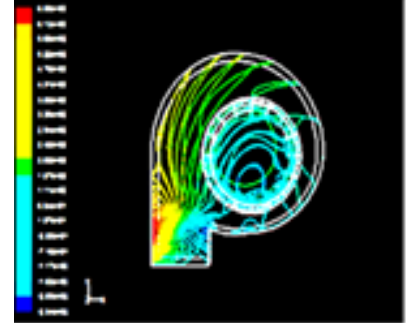

(a)

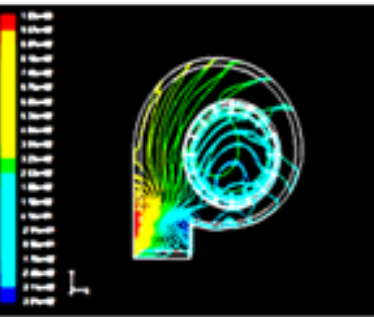

(c)

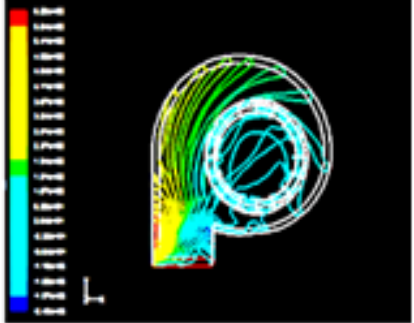

(b)

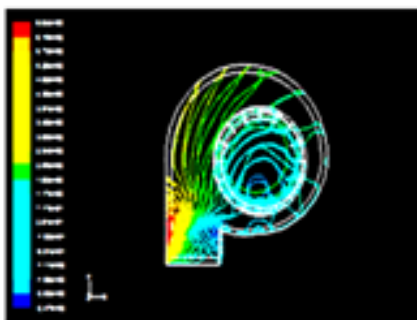

(d)

Fig. 4. The contours of static pressure for the diverse configurations of serrated blades at the impeller speed of 800 RPM. (a) USB, (b) ISB, (c) OSB, and (d) BSB configuration 


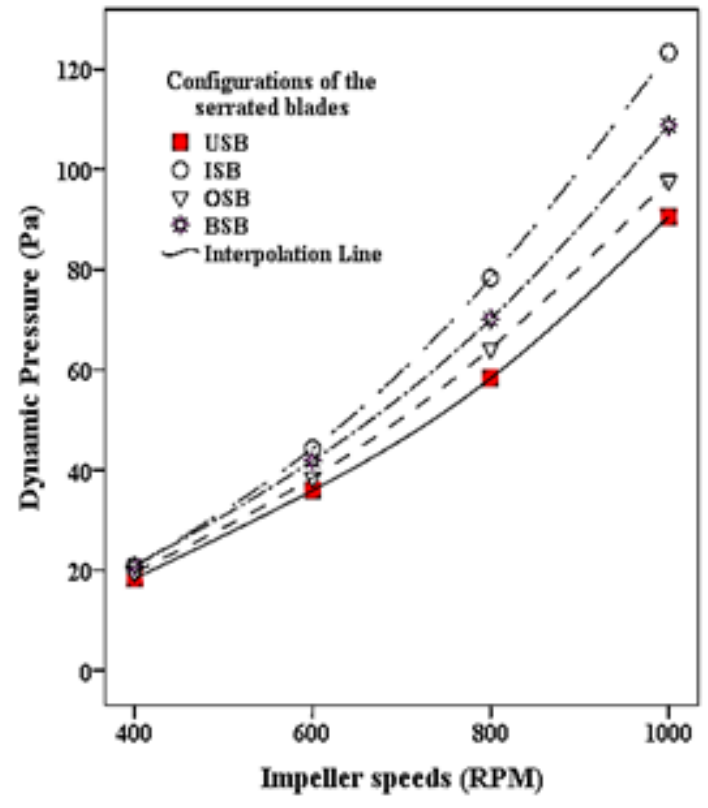

Fig. 5. The result of dynamic pressure in the fluid flow zone

The simulation results in the fluid flow zone indicated that dynamic pressure increase with the increase of the impeller speed in all the configurations. The highest value is achieved by the ISB configuration at each level of the impeller speed, as shown in Fig. 5. The effect of dynamic pressure cause the decreasing airflow velocity that confined by a number of blades in the inner chamber of the impeller. Reducing the surface areas of blades by making the serrated blades can alleviate flow resistance so that the dynamic pressure of the fan increased.

\section{Air Velocity}

The result of air velocity on the serrated blade configurations and impeller speeds in the fluid flow zone is illustrated in Fig. 6 below

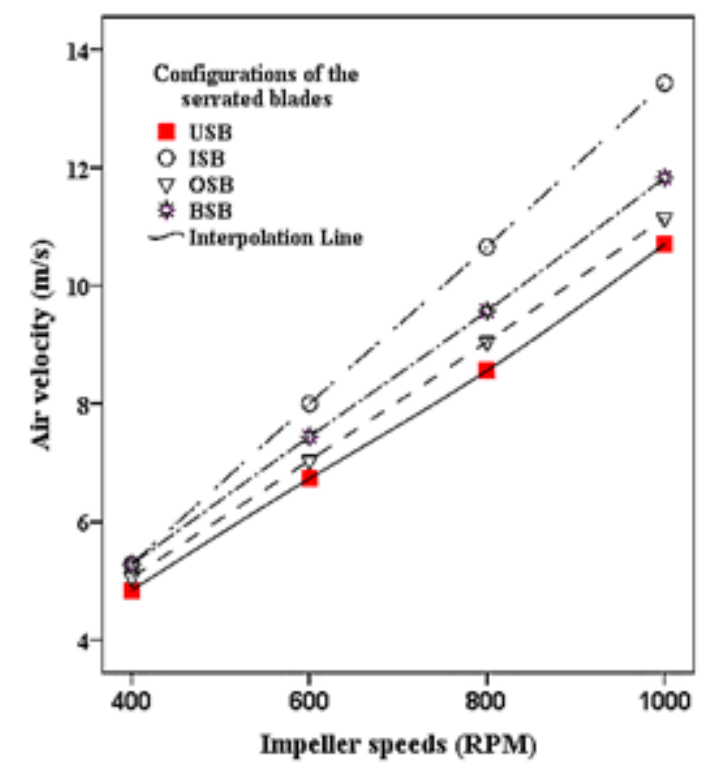

Fig. 6. The result of airflow velocity in the fluid flow zone 
In Fig. 6 showed that the increase of air velocity is caused by increasing the impeller speed in all the zones, except in the inlet zone. In the fluid flow zone, it obtained the high values of air velocity for the configurations of serrated blades (ISB, OSB, BSB) compare to the USB configuration.

At the serrations of the airfoil occur the sharpen increasing of the normal velocity fluctuation of the wall on the pressure side of the blades [22,23]. The design of the serrated edge of an airfoil of the fan could change the behavior of flow fields so that it might affect flow velocity [24]. In literature $[25,26]$ air velocity at the outlet related to the volumetric flow rate in the inlet because it prevailed the law of flow continuity in the centrifugal fan so that depends on the air velocity and diameter of the inlet.

\section{Turbulent Kinetic Energy}

The simulation results of TKE on the serrated blade configurations and impeller speeds in the outlet zone and the wall zone are shown in Fig. 7.

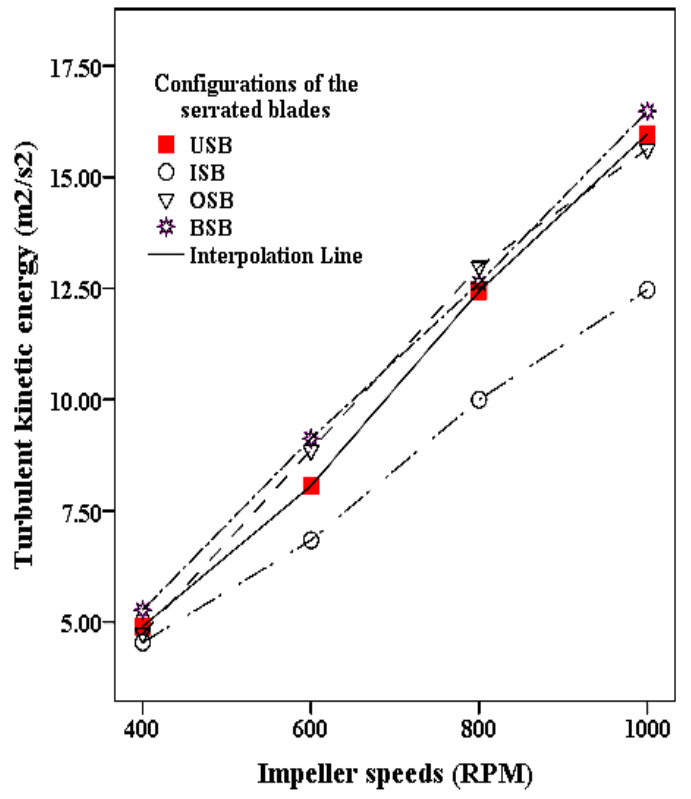

(a)

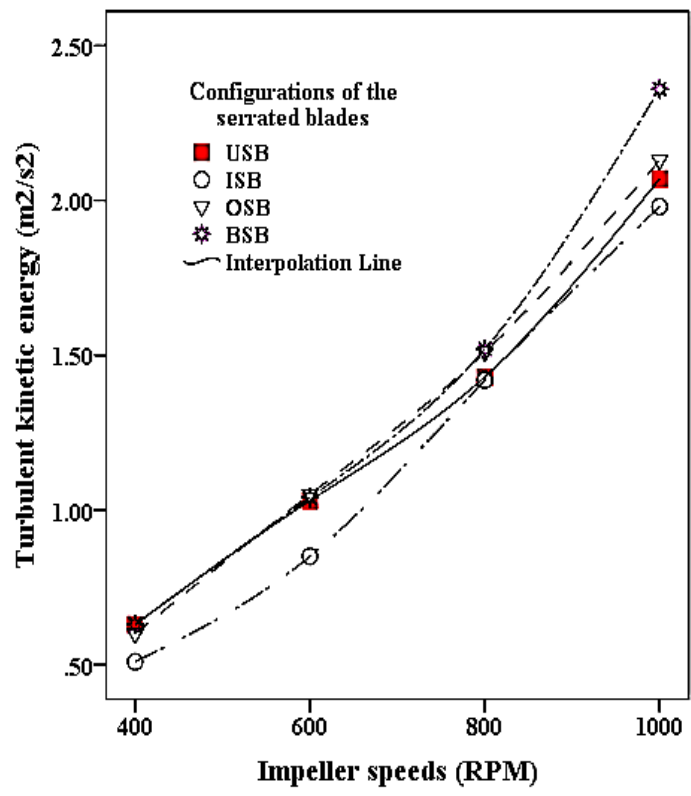

(b)

Fig. 7. The result of TKE in (a) the outlet zone and (b) the wall zone

Fig. 7 showed that TKE increase with increasing the impeller speeds for all the configurations in the outlet zone and wall zone. The ISB configuration generates the lower TKE about 4.54-12.47 $\mathrm{m}^{2} \mathrm{~s}^{-2}$ in the outlet zone (Fig. 7a). It produces the lower TKE about $0.51-12.47 \mathrm{~m}^{2} \mathrm{~s}^{-2}$ in the wall zone (Fig. 7b). While the BSB configuration achieved a higher TKE compare to the other configurations. It had two serrated sides that might produce two flow patterns different at the tip of the blades. By this condition would collide with each other so that it produces a high TKE in the fluid flow zone. In reference [25] turbulences occur when the velocity of the airflow and or the direction of movement changes rapidly in airflow non-laminar and complex. This because the zone between the impeller and wall could generate pressure, temperature difference, and friction of airflow. Besides that, the rotating impeller produces aerodynamic forces. In reference [27] the high turbulence occurs in the zone between one-third of the impeller width and the inlet. It is normally because of the high discharge pressure that generated the flow restrictions in the centrifugal fan.

The ISB configuration with the lower TKE in all zone, except in the impeller zone. These are indicated by the number of contour lines are smaller and the densities of the lines is loose at each the zones. If compared to the other configurations. This can be shown in Fig. 8. Researchers that investigated [28] the formations and dimensions of the serrated blades significantly affect fan turbulence. The fan blade with the depth serrations could help in reducing flow resistance thereby reducing airflow turbulence. 


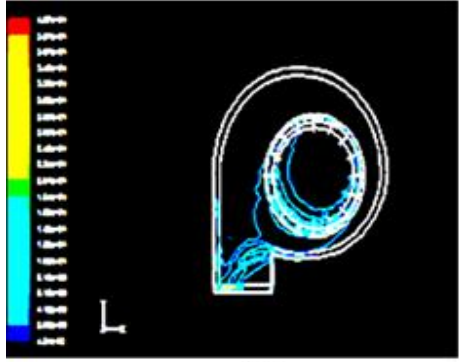

(a)

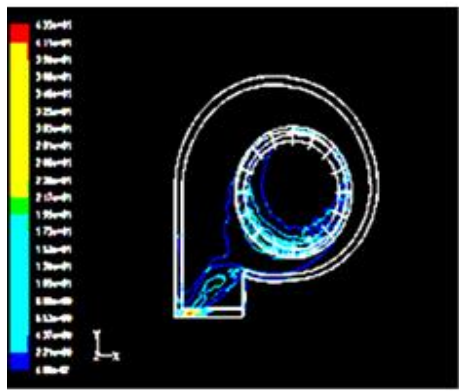

(c)

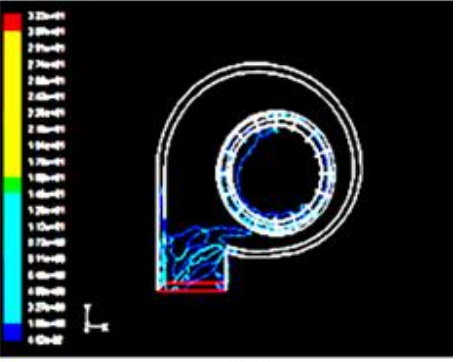

(b)

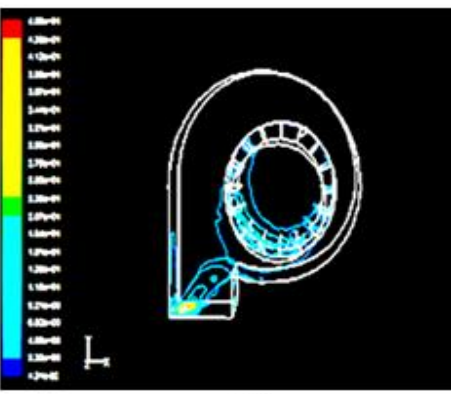

(d)

Fig. 8. The contours of TKE for the diverse configurations at the impeller speed of 600 RPM.

(a) USB, (b) ISB, (c) OSB, and (d) BSB configuration

\section{Statistical Analysis Results}

The analysis results of the ANCOVA test are based on all the data of the configurations of the serrated blades and the impeller speed levels on the airflow characteristics in all the zones. This can be seen in Table 4. The results of the ANCOVA test indicate that the effect of the impeller speed is very significant $(\alpha<0.01)$ on the airflow characteristics in all the zones, except for static pressure is no significant $(\alpha>0.05)$ in the impeller zone and fluid flow zone. The increase of the impeller speed causes static pressure, dynamic pressure, and energy of airflow increased in the modification centrifugal fan.

Table 4. The results of ANCOVA test of the fluid flow characteristics in the all zones

\begin{tabular}{|l|c|c|c|c|c|}
\hline \multirow{2}{*}{ Variable Sources } & \multicolumn{6}{|c|}{ Value of F ratio and significant } \\
\cline { 2 - 6 } & $\begin{array}{c}\text { Inlet } \\
\text { zone }\end{array}$ & $\begin{array}{c}\text { Impeller } \\
\text { zone }\end{array}$ & $\begin{array}{c}\text { Fluid } \\
\text { flow zone }\end{array}$ & $\begin{array}{c}\text { Wall } \\
\text { zone }\end{array}$ & $\begin{array}{c}\text { Outlet } \\
\text { zone }\end{array}$ \\
\hline \multirow{7}{*}{ Static Pressure } \\
\hline Impeller speed & 22.510 & 3.256 & 0.035 & 58.94 & 328.08 \\
& $0.001^{* *}$ & $0.099^{\mathrm{ns}}$ & $0.855^{\mathrm{ns}}$ & $0.000^{* *}$ & $0.000^{* *}$ \\
\hline Configuration & 24.784 & 0.191 & 4.285 & 9.487 & 0.613 \\
& $0.000^{* *}$ & $0.900^{\mathrm{ns}}$ & $0.031^{*}$ & $0.002^{* *}$ & $0.621^{\mathrm{ns}}$ \\
\hline \multicolumn{7}{|c|}{ Dynamic Pressure } \\
\hline Impeller speed & $208.32^{*}$ & 511.15 & 294.96 & 137.37 & 653.01 \\
& $0.000^{* *}$ & $0.000^{* *}$ & $0.000^{* *}$ & $0.000^{* *}$ & $0.000^{* *}$ \\
\hline Configuration & 0.000 & 1.119 & 3.477 & 1.1611 & 0.042 \\
& $1.000^{\mathrm{ns}}$ & $0.383^{\mathrm{ns}}$ & $0.054^{\mathrm{ns}}$ & $0.372^{\mathrm{ns}}$ & $0.988^{\mathrm{ns}}$ \\
\hline Impeller speed & 399.22 & 2484.27 & 593.03 & 1116.20 & 296.99 \\
& $0.000^{* *}$ & $0.000^{* *}$ & $0.000^{* *}$ & $0.000^{* *}$ & $0.000^{* *}$ \\
\hline Configuration & 0.000 & 8.578 & 12.009 & 6.666 & 1.675 \\
& $1.000^{\mathrm{ns}}$ & $0.003^{* *}$ & $0.001^{* *}$ & $0.008^{* *}$ & $0.235^{\mathrm{ns}}$ \\
\hline
\end{tabular}




\begin{tabular}{|l|c|c|c|c|l|}
\hline \multicolumn{7}{|c|}{ Turbulent Kinetic Energy } \\
\hline Impeller speed & 331.69 & 191.82 & 234.66 & 497.06 & 527.67 \\
& $0.000^{* *}$ & $0.000^{* *}$ & $0.000^{* *}$ & $0.000^{* *}$ & $0.000 * *$ \\
\hline Configuration & 1.410 & 12.686 & 1.316 & 2.586 & 10.383 \\
& $0.292^{\mathrm{ns}}$ & $0.001^{* *}$ & $0.318^{\mathrm{ns}}$ & $0.106^{\mathrm{ns}}$ & $0.002 * *$ \\
\hline
\end{tabular}

Note: $* *$ is very significant $(\alpha<0.01), *$ is significant $(\alpha<0.05)$, and ${ }^{\mathrm{ns}}$ is no significant $(\alpha>0.05)$

Table 4 indicates that the effect of the configurations of serrated blades is very significant ( $\alpha$ $<0.01)$ on static pressure in the inlet and wall zone, and significant $(\alpha<0.05)$ in the fluid flow zone. Meanwhile, the effect of the configuration is no significant $(\alpha>0.05)$ on dynamic pressure in all the zones. It is very significant $(\alpha<0.01)$ to air velocity in the impeller zone, fluid flow zone, and wall zone. While, it is very significant $(\alpha<0.01)$ on TKE in the impeller zone and outlet zone

\section{CONCLUSIONS}

The simulation results show that the BSB configuration achieves the high static pressures about 84.5214.7 $\mathrm{Pa}$ in the wall zone. While the ISB produces the lower TKE in all the zones, except in the impeller zone. It produces about $0.51-12.47 \mathrm{~m}^{2} \mathrm{~s}^{-2} \mathrm{TKE}$ in the wall zone.

The results of the ANCOVA test indicate that the effects of the impeller speed are very significant $(\alpha<0.01)$ on the airflow characteristics in all the zones, except for static pressure is no significant $(\alpha$ $>0.05)$ in the impeller zone and fluid flow zone. The effect of the configuration of serrated blades is very significant $(\alpha<0.01)$ on static pressure in the inlet and wall zone, and significant $(\alpha<0.05)$ in the fluid flow zone. While it is very significant to air velocity in the impeller, fluid flow, wall zone; and it is very significant $(\alpha<0.01)$ on TKE in the impeller zone and outlet zone. Meanwhile, it is no significant $(\alpha>0.05)$ on dynamic pressure in all the zones.

\section{ACKNOWLEDGEMENTS}

The author would like to thank the support provided by Agriculture Polytechnic of Pangkep State in the form of providing equipment for this research.

\section{REFERENCES}

[1] A. Corsinia, G. Delibraa, F. Rispolia, A.G. Sheardb, P. Venturini, Aerodynamic simulation of a high-pressure centrifugal fan for process industries. Proceedings of ASME Turbo Expo 2013: Turbine Technical Conference and Exposition GT2013, San Antonio, Texas, USA. (2013) 1-11.

[2] Z. Lin, Numerical study of aerodynamic characteristics on the wind turbine airfoil with leading and tailing edges protuberances. Fluid Machinery. 40 (2012) 27-31.

[3] S. Thangarasu, G. Sureshkannan, N.V. Dhandapani, Design and experimental investigation of forward curved, backward curved and radial blade impellers of centrifugal blower. Australian Journal of Basic and Applied Sciences. 9(1), (2015) 71-75.

[4] R. Raggoth Singh, M. Natraj, Optimizing impeller geometry for performance enhancement of a centrifugal blower using Taguchi quality concept. International Journal of Engineering and Science Technology. 4(10), (2012) 4308-4314. 
[5] E. Rusiński, P. Moczko, P. Odyjas, D. Pietrusiak, Investigation of vibrations of a main centrifugal fan used in mine ventilation. Archives of Civil and Mechanical Engineering. (2014) 1-11. http://www.elsevier.com/locate/acme.

[6] M. Younsi, F. Bakir, S. Kouidri, R. Rey, Influence of impeller geometry on the unsteady flow in a centrifugal fan: numerical and experimental analyses. International Journal of Rotating Machinery. (2007) 1-10.

[7] F. Tong, W.Y. Qiao, L. Wang, Noise reduction mechanism of bionic airfoil trailing edge serrations. Acta Aeronaut Astronaut Sinica. 36 (2015) 2911-2922.

[8] T.V. Valkov, C.S. Tan, Effect of upstream rotor vertical disturbances on the time-average performance of axial compressor stators, part I - Framework of technical approach and wake stator blade interactions. ASME Journal of Turbomachinery. 121 (1999) 377-386.

[9] W. Zhang, J. Yuan, B. Zhou, H. Li, Y. Yuan, The influence of axial-flow fan trailing edge structure on internal flow Advances. Advance in Mechanical Engineering. 10(11), (2018) 1-12.

[10] L.E. Jones, R.D. Sandberg, Acoustic and hydrodynamic analysis of the flow around an aerofoil with trailing-edge serrations. Journal of Fluid Mechanics. 706 (2012) 295-322.

[11] K.L. Hansen, R.M. Kelso, B.B. Dally, Performance variations of leading-edge tubercles for distinct airfoil profiles. American Institute of Aeronautics and Astronautics Journal. 49(1), (2011)185-194.

[12] Dhyanjyoti Deb Nath, K. Viswanath, A.B. Patel, Experimental study of the effect of serrations on axial flow fan blade trailing edge. Proceedings of the ASME 2016 International Mechanical Engineering Congress and Exposition, Phoenix-Arizona, USA. (2016) 1-12.

[13] H.A. Alawadhi, A.G. Alex, Y.H. Kim, CFD analysis of wing trailing edge vortex generator using serrations. EPJ Web of Conferences 67, 02002. (2014) 1-8.

[14] Zaimar, Mursalim, H. Abbas, Supratomo. Performance testing of a modified centrifugal fan with serrated blade impeller. International Journal of Science and Technology Research. 6(10), (2017) 122-125.

[15] F. Shigehisa, I. Taku, H. Kiyotaka, M. Fukaya, Platform technology for computational fluid dynamics supporting design of system products - from power plants and industrial machinery to home appliances. Hitachi Review. 61(6), (2012) 244-248.

[16] P. Chand, S. Rai, Centrifugal fan impeller design with optimization of blade. International Journal of Applied Engineering Research. 7(11), (2012) 2082-2089.

[17] A.T. Oyelami, S.B. Adejuyigbe, Waheed, A.K. Ogunkoya, D. Iliya, Analysis of radial-flow impellers of different configurations. The Pacific Journal of Science and Technology. 13(1), (2012) 24-33.

[18] S.K. Kusekar, A.K. Lavnis, Optimization of critical parts of centrifugal blower by modal \& CFD analysis. International Journal of Innovative Research in Advanced Engineering. 1(12), (2014) 69-82. 
[19] Lumamaheswararao, M. Ashif, Fluid flow analysis of centrifugal fan by using FEM. International Journal of Mechanical Engineering and Technology. 7(2), (2016) 45-51.

[20] F. Tuakia. The fundamentals of CFD by using FLUENT. Publishing of Informatika, Bandung, Indonesia. (2008) 9-194.

[21] P.N. Son, J.W. Kim, E.Y. Ahn, Effects of bell mouth geometries on the flow rate of centrifugal. Journal of Mechanic and Science Technology. 25(9), (2011) 2267-2276.

[22] L. Anggraini, Analysis of Porosity Defects in Aluminum as Part Handle Motor Vehicle Lever Processed by High-pressure Die Casting. In IOP Conference Series: Materials Science and Engineering, 367 (2018) 012039.

[23] C. Arce Leon, R. Merino-Martinez, D. Ragni, F. Avallone, F. Scarano, S. Probsting, M. Snellen, D. Simons, J. Madsen, Effect of trailing edge serration-low misalignment on airfoil noise emissions. Journal of Sound and Vibrations. 405 (2017) 19-33.

[24] M. Howe, Noise produced by a sawtooth trailing edge. Journal of the Acoustical Society of America. 90 (1991) 482-487.

[25] Austin H. Church, Centrifugal fan and blower. John Wiley \& Son. Publishing. New York (1986).

[26] L. Anggraini, Y. Natsume, K. Ameyama, Effect of particle shape on dispersion formation of harmonic microstructure of Si3N4-ZrO2. In Materials Science Forum. 864 (2016) 47-51.

[27] S. Khelladi, S. Kouidri, F. Bakir, R. Rey, Flow study in the impeller-diffuser interface of a vane centrifugal fan. ASME Journal of Fluid Engineering. 127 (2005) 495-502.

[28] X. Liu, H. Kamliya Jawahar, M. Azarpeyvand, Wake development of airfoils with serrated trailing edges. In 22nd AIAA CEAS Aeroacoustics Conference. American Institute of Aeronautics and Astronautics. (2016) 1-21. 